Charalambos Tsekeris ${ }^{1}$

National Centre for Social Research

Athens (Greece)

Persefoni Zeri ${ }^{2}$

Panteion University of Social and Political Sciences

Athens (Greece)
616.98:578.834]:316.774/.776(100)"2020"

316.324.8:[616.98:578.834(100)"2020"

Original scientific paper

Submitted 27/07/2020

Revised 22/08/2020

Accepted 22/08/2020

doi:10.5937/socpreg54-27687

\title{
THE CORONAVIRUS CRISIS AS A WORLD-HISTORIC EVENT IN THE DIGITAL ERA
}

Abstract: The world-historic event of the COVID-19 pandemic has once more confirmed that we live in a hyperconnected world society and that, nowadays, epidemics do not count as merely natural phenomena anymore. In such context, the present paper aims to interpret the complex relationship between the society and COVID-19, with emphasis on the role played by different forces in the field of information policy and public perceptions in general. For this reason, we elaborate on cultural factors, as well as on emotions like responsibility, trust, and fear during the crisis. We also focus on the dynamics of contemporary media in relation to public images of the pandemic, drawing upon relevant findings. Overall, this casts a fresh sociological and interdisciplinary light on the current pandemic as a relational process and a digital media-driven phenomenon.

Keywords: coronavirus crisis, digital media, trust, fear, Greece

\section{Introduction: State, society and the coronavirus crisis}

A foresight study on the scenario of a great pandemic coming from Asia was given to all members of the German Parliament in 2012 (Kiel, 2020). Interestingly, the study was not taken into account at all. Everybody ignored the weak signals. In the beginning of 2020, the coronavirus (or COVID-19) pandemic came unexpectedly in the West as a superspreader-driven "black swan", an extreme fat-tailed process (Taleb, 2020) owing to an increased global connectivity. It seems that all national and supra-national governments were unprepared for it, although governing in principle pertains to strategic reflection and anticipation (Tufekci, 2020). Anticipation scenarios assume futures thinking and specific structures for the implementation of emergency measures, based on clear responsibilities, risk assessment, and experts' participation (Kiel, 2020).

What happens now in the West is an open process of defining and containing the coronavirus pandemic, in which science (epidemiology, infectology, immunology, virology),

\footnotetext{
1 tsekeris@ekke.gr

2 persazeri@hotmail.com
} 
under conditions of high uncertainty and unpredictability, plays a leading role, combined with a public debate on the perspectives over the medical treatment of the disease, something that varies over time. In these public deliberations, many diverse actors participate in an active way, such as the printed and digital media, civil society, and other stakeholders. A positive role in this information pool about the pandemic is played by the global research network of universities and research institutions, which intensively cooperate on COVID-19 response. This constitutes a general knowledge base that flows in the process of the political decision making (Dianeosis, 2020). The popular belief in the active confrontation and successful mastery of the crisis helps large-scale behaviour change, or creates the readiness to comply with the required behavioral orientation (Dianeosis, 2020).

In such process, people express the readiness to take over the responsibility for themselves and the others, thus following specific behavioural rules of hygienic conduct, such as handwashing, wearing a mask, and social distancing. In this regard, governments attempt to combine the responsibility shown by the people with the public adherence to the required rules, something that signifies the constitutive role the state plays for the protection of society. The public respect to containment measures (closing schools, banning large public gatherings and team events, and so on) demonstrates the unconditional acceptance of the political as the supreme responsible of the functioning of a society as a whole. The civil society (or the family) cannot act alone in this situation; it needs the state. This fact becomes evident in the mobilisation of financing measures of immense proportions for the support of economy and society that were deeply affected by the crisis (Strauss-Kahn, 2020, p. 9; Rogoff, 2020). Both the immediate response of the majority of the European states to the crisis and the high approval by the public of the drastic measures has to do with the ultimate "value of the human life that has been considerably reinforced in the collective unconscious of the richest countries" (Strauss-Kahn, 2020, p. 8). Economy and other social activities must therefore sacrifice part of their dynamics in favour of the health system (Baecker, 2020a). In this historic occasion, we witnessed the "paradox" for democratic societies that collectivity is inscribed in the service of a simply defensive cause (Gauchet, 2020c).

The coronavirus containment and social distancing measures indicate a radical shift of emphasis from a culture of freedom and self-determination to a culture of the vulnerability of the protection (Bude, 2020) and of collective discipline. This change indicates a weakening of the dominant idea of a strong "I", of the "identitarian person" (Ladeur, 2007, p. 397), who negates the internalisation (or indoctrination) of social constraints and is focused on itself and its allegedly "authentic" self-presentation, away from the common reality. Instead, we now witness the prevalence of the idea of a weak and vulnerable "I" that needs the state protection. The answer given by the public authorities in Greece, like in the most countries, particularly around the confinement and lockdown measures, has been accepted and respected by the vast majority of the population (Dianeosis, 2020; Papamattheou, 2020).

During the confinement period, citizens could reflexively observe the emergence of the perception of a new, effective "We" (Coyle, 2020), bound to an idea of personal pro-social development and broader societal integration and cohesion. This also has to do with the set back of the political polarisation, which is endemic in the Greek political life (Zeri et al., 2019). But is this a dynamical set back? Of course, no one can easily predict whether a revival of the poisonous political climate will take place after the coronavirus crisis, especially in the context of an economic crisis that will probably follow, with unknown extent 
(European Commission, 2020). In any case, the task of politics, in view of the scientific uncertainties concerning the discovery of a vaccine or effective drugs, is to develop a capacity of collective action and to inspire society with a strong belief in the successful collective response to the crisis. The government must also discern and employ communication strategies that strike a sensitive "balance between breaking through optimism bias without inducing excessive feelings of anxiety and dread" (Bavel et al., 2020, p. 461). In addition, leadership must coordinate individuals and "help them avoid behaviours that are no longer considered socially responsible" (Bavel et al., 2020, p. 465).

The state interference has neither to do with a technocratic, naïve subordination to science, nor with an authoritarian readiness to comply. There was a feeling among citizens that we need the democratic state that represents all of us and has sanction powers over the individuals for the common good (Bude, 2020). Public protection is one of the central aims of democratic politics, especially in the strategic effort to express a compelling public interest (Gostin \& Wiley, 2020) and to make people survive this world-historic phenomenon of the coronavirus with unity and solidarity (Visvizi and Lytras, 2020), as well as with our humanity intact. Interestingly, the Dianeosis (2020) survey results confirm the image Greeks have about a state that gives priority to public health, as well as to the knowledge and responsibility of the experts. At least temporarily during the confinement, we witnessed the spontaneous emergence of a mechanism of solidarity and mutual care (Fanaras, 2020, p. 17) that was not enforced in a top-down way, but based on the feeling that, after all, we do need the state.

We also witnessed an atmosphere of reserved solidarity (or an idiosyncratic mixture of solidarity and suspicion), whose nature has taken a new dimension; that is, we protect the others not only by helping them, but also through "keeping distance", so that they will not be infected. The consciousness of a relatively class-neutral vulnerability has stimulated the search for new solidarity forms. Interestingly, $66.8 \%$ of Greeks believe that the coronavirus crisis has a positive impact on the solidarity to the Other (Georgakopoulos, 2020, p. 10). However, it is still early to draw final and decisive conclusions about a learning process that refers to the consolidation of new types of solidarity. Recent images of mass demonstrations and social gatherings in public spaces, while the rules of social distancing are still in force, may be indicative of a lack of civic mindedness and, perhaps, of a cultural incapacity to remember. We now proceed to elaborate on the role played by different forces, such as emotions, culture and the media, in the field of information policy, public perceptions on COVID-19, and the pandemic society in general.

\section{Responsibility and trust during the pandemic}

In the period of implementation of the "stay-at-home" orders and total confinement, the overload of public information (flooded with guidelines managed by the Greek state and broadcasted by television and radio) helped people realize that they are responsible not only for themselves, but also for the others. During the two months of quarantine, social members have learnt to comply to the mandatory rules. The severity of the crisis was made clear after having experienced the media images from Italy and USA showing convoys carrying coffins of coronavirus victims out of Bergamo or New York and the overwhelmed health-care systems. Given that the pandemic is most dangerous for the elderly and that, 
within the Greek family, the grandparents play a vital role (Dianeosis, 2020), there was almost absolute respect to the lockdown measures.

The loosening of the confinement measures in May 2020 was connected to strict preconditions that obliged people to abide by restrictive measures. But youngsters and the more vulnerable old people have suddenly come to mass gatherings in parks and places by the sea, thus massively breaking the social distancing rules. They acted as if they have erased from their memory the risks of a new COVID-19 outbreak, as well as the media warnings by the highly respected Professor Sotiris Tsiodras, the immunology experts group leader and government's communications liaison for the health crisis (Kathimerini, 2020). That is, a sudden turn from a collectively disciplined people to a public interest-defying people. It is hereby evident the fragility of the fear-driven unity and cohesion demonstrated in the confinement period, but also the deep desire for normalcy.

In the European consciousness, peace and prosperity, combined with high economic performance, have downplayed strategic futures/foresight thinking and diluted the anticipation of threat and the fundamental dimension of the political existence. The emphasis on individual rights and material resources has become the only conceivable horizon, thus creating an ill-founded feeling of security (Gauchet, 2020a). Besides, there has been some diversity in people's attitudes among different European countries regarding the confinement measures against the coronavirus. The Catholic countries, such as Italy and France, stand out with a combination of private anarchy and public authoritarianism, while the protestant countries rather rest on a sense of personal responsibility (Gauchet, 2020a).

In Greece, in particular, we have neither the legacy of the Confucian discipline, nor can we refer back to a heritage of modernity and a deeply enshrined consciousness of personal responsibility. Practicing personal responsibility does not belong to the self-instituting political community "texture" of the Greek society, which is full of deeply rooted pre-modern cultural patterns (Demertzis, 1997, p. 109; Zeri et al., 2019, p. 8). In some way, the Greek individual subject is caged in an unreflected "entrenched self" (Ramfos, 2011) and bears the social and psychological prescriptions as well as the moral assumptions of the family mindset and strategy embedded in wider networks of interest groups (Pelagidis, 2012). Nevertheless, a value change in the post-crisis era is certainly possible and worthy of analysis.

Confronting a massive health crisis, such as the COVID-19 pandemic, which pertains to a total social fact (Kasuga, 2020), Greeks fall back on the state for protection. The myriad media images of death have generated a psychological shock that could be soothed only in the pursuit of unity and cohesion. The unity of the people constructs itself around the state and its representatives as the condition of being together, not in the context of Europe or other supranational organisations. However, it is noteworthy that the attitudes of Greeks towards their political institutions have been rather negative (Koniordos, 2018). The successful management by the Mitsotakis government of the Evros crisis (January 2020) and of the coronavirus crisis (March-April 2020) signified a remarkable change in the image Greeks have about their political institutions, especially about their government.

In comparison to the previous Dianeosis surveys, the coronavirus crisis survey of Dianeosis in April 2020 has showed a conspicuously higher level of people's trust towards the state institutions, followed by a strengthening of their feelings of optimism, security, and certainty at personal level (Dianeosis, 2020). Also, the state measures taken during the pandemic for the improvement of the public health care system have ameliorated the trust 
towards the state itself (see Kounias, 2020). Notably, trust to (medical) science is at the highest point of the scale. According to the corona survey of the Economic University of Athens, $50 \%$ of the respondents have trust in the doctors, $88 \%$ in the health workers, and $57 \%$ in the state, although they have low trust in teachers (45\%) and private companies (24\%), while $75 \%$ believe that the confinement measures were effective (Papamattheou, 2020). Interestingly, political trust, clear messages, transparent communication and outreach on all matters at stake is crucial to spur behavioural change (Bavel et al., 2020, p. 466). Moreover, the political management and mastery of the post-COVID-19 economic recession will arguably be a decisive factor for the development of generalised trust in Greek politics.

\section{Fear in the coronavirus era}

The 9/11/2001 terrorist attacks in New York signified an age of fear. In the course of time, feelings of fear have been variously linked to Islamist terrorism, to the threatening climate change, and now to the massive global health crisis that seriously affects all of us (Bolz, 2020). In the contemporary affluent society, many people perceive the COVID-19 pandemic as an unprecedented fight for survival. Until now, the state was put at the service of economy, promoting the free circulation of capital, people and goods. After the global spread of the life-threatening coronavirus, the state has slowed down the economy because the human lives were in danger. This is a confirmation of the respect of the humanist dimension claimed by modernity. It is not salvation, in the sense of a religious redemption (Finkielkraut, 2020a), but health that remains from the beginning of the modern times "the first good and the foundation of all the other goods of this life" (Descartes, 1953 [1637], p. 168). In Alain Finkielkraut's words, we must be

"grateful to the politicians for whom human life is more important than money. They have set the right priorities, because they want to save the most weak and vulnerable members of society. [...] As long as the life of an old man is only worth as much as the life of a man in full possession of his physical strength, we remain civilized" (Finkielkraut, 2020b).

However, within a democratic community, especially during periods of social calm, people give priority to their individual freedoms. Yet, the collective machinery at normal times makes us forget that we are a political community (Gauchet, 2020b). In view of an acute crisis and a collective threat, fear and a sense of general vulnerability energise people's capacity to act as citizens who owe their protected existence to their political community, while the priority of their personal freedoms is relatively reduced. In the same time, unlike the dictatorial or authoritarian regimes, people (internet users) have the freedom to discuss in public and reflect on the motives of the public actions.

According to Dianeosis research results (Fanaras, 2020, p. 6), the Greek government's successful management of the coronavirus crisis has kept the negative feelings of fear and anxiety within limits. The confinement of the whole society for more than six weeks had been surprisingly confronted with patience and creativity. Almost similar results were produced by the Coronavirus Disruption Project (Center for the Digital Future, 2020), according to which Americans, during the pandemic, were enjoying more time with their partners and children, rediscovering hobbies and creative activities. Notably, the corona survey of the Economic University of Athens (Papamattheou, 2020) refers to high levels of fear and anxiety about economy (92\%) and less about health (82\%). 


\section{Media and the coronavirus crisis}

The coronavirus pandemic has made evident the high complexity of the global system and its increased non-linear dynamics (Tufekci, 2020), given that the structural form of the world society (Baecker, 2020b) and the national societies pertains to relational networks which variously differentiate and reproduce themselves (Baecker, 2018, p. 61). In particular, the health crisis we are now experiencing is quite different from what we know from the past, precisely for the reason that every economy nowadays is globally integrated in a wider global context, where China constitutes the "factory of the world" (Strauss-Kahn, 2020, p. 19) and the memory of an infectious pandemic risk is lost. In this analytic setting, it is of crucial importance to elaborate on the fact that, within the network society in which we live, the media, as a form of collective reflection and orientation, have taken the place of politics, economy and religion (Baecker, 2018, p. 192). For this reason, varying degrees of quality information access can greatly influence health perceptions, behaviours, decisions and outcomes in pandemic contexts, where online disinformation may lead to death and disease in the real world (McGinty \& Gyenes, 2020, p. 4). The latter has led the Greek government (in line to other EU governments) to set up a webpage devoted to deconstruct the myths about COVID-19 (covid19.gov. gr/mythoi-covid19/), as part of the official COVID-19 observatory portal (covid19.gov.gr).

Moreover, the media are framed in different historical, cultural and institutional contexts of current societies, which relationally shape their technological systems and patterns of transmission in the era of globally networked communications. This points to the fundamental role that the printed and digital media play in the information policy of national governments, as well as in the public perception of the pandemic (see e.g. Casero-Ripolles, 2020). According to a recent survey of the University of Chicago (Bertrand et. al, 2020), Americans see the pandemic not through the lens of health and economics, but through the lens of their political beliefs, their opinion on the proper role of government, and their trust in media under the condition of a politically divided society. The trust in media is quite crucial for the assessment of and the response to the pandemic (see Merrefield, 2020). It is noteworthy that the majority of people do not assess the pandemic on the basis of what they have seen or heard during the public discussions, but according to whom they vote for, what media they follow, or whom television host they prefer (Bursztyn et al., 2020).

According to a survey research conducted by the Pew Research Center, the ideological makeup and the party orientation of the cable network audiences influence the way they assess the coronavirus epidemic (Pew Research Center, 2020a). Although the American public says the media have done well covering the crisis, deep partisan divisions about the media's coronavirus coverage were evident not only between voters of Democrats and Republicans, but also among ideological segments within each party (Pew Research Center, 2020d). For instance, in a recent US survey (Jamieson \& Albarracin, 2020), it was found that mainstream broadcast media use (e.g. NBC News) correlated with accurate information about the disease's lethality, and mainstream print media use (e.g. New York Times) correlated with accurate beliefs about protection from infection, while conservative media use (e.g. Fox News) correlated with conspiracy theories.

Nowadays, electronic and digital news media are flooded with negative, sensationalist and misinformation-type news stories about the pandemic. In the mass media, it is well known how journalists turn anything into bad news, because they aim at a mass audience 
affected in principle by negative news (Tierney, 2020). Negativity biases and negative information are one of the most basic psychological principles (Baumeister, 2020). In addition, they constitute a key fact about how the human mind works. People have a propensity to give more weight to things that go wrong than to things that go right, so much that just one negative event can hijack our mind (Baumeister \& Tierney, 2019). Negative information puts a kind of stump in the human mind, and it is not easy to remove it (Sunstein, 2020). Evidently, we unconsciously tend to pay attention to bad news (Hancock, 2020). As Guglielmo Briscese puts it, the more people are infected, the closer the pandemic gets, and yet people do not change their views (see Merrefield, 2020).

Cognitive and negativity biases have great impact upon how we process news (McIntyre, 2020). Our brain's confirmation bias drives us to seek out only information which is aligned with what we already believe and to discredit the rest. Biases like these can prevent us from learning from news about the pandemic and fight it effectively (McIntyre, 2020). But, in the pandemic society, people often live in personal emergency situations, which can overturn in a genuine world of delusion, and reflect the enormous fragility of the psyche. This helps the flourishing of corona conspiracy theories across all segments of society (Bavel et al., 2020, p. 464ff.). In times of helplessness and lack of stability, because important psychological needs are frustrated, conspiracy theories function as an instrument of personal crisis management (Douglas et al., 2017). Social media architecture somehow facilitates the flourishing and spread of false information and fake news about the coronavirus around the world, despite the coordinated efforts by some digital platform companies (Fraenkel et al., 2020). In addition, Jan Philipp Reemtsma (2020) stresses that political thinking is overestimated and, actually, affects play a crucial role (see also Demertzis, 2020). People have rarely a political way of thinking (Reemtsma, 2020).

The way in which Americans follow news sources for coronavirus news and perceive media's pandemic coverage differ essentially from the way in which Greeks use information sources for coronavirus news and particularly the news media. Most Americans have paid equal attention to national and local COVID-19 news, whereby $56 \%$ national news outlets (including newspapers) are a major coronavirus news source, $51 \%$ the public health organisations and officials, $46 \%$ local news outlets, $31 \%$ Donald Trump and the White House coronavirus task force, $25 \%$ the international news outlets, $10 \%$ online forums and discussion groups, $16 \%$ friends, family and neighbors (Pew Research Center, 2020b). Nearly nine-in-ten think that the internet is an essential or important tool during the coronavirus outbreak (Pew Research Center, 2020c). In Greece, the use of coronavirus news sources is accompanied by an increase in trust to the news media (Fanaras, 2020), something that gets in line with the aforementioned increase in the trust to the political institutions and especially to the Greek government. For Greeks, the main coronavirus news source is television (48\%), followed by internet sites $(25.4 \%)$, health officials $(9.1 \%)$, social media $(7.5 \%)$, radio $(3.7 \%)$, family and friends $(2.9 \%)$, and newspapers $(1.8 \%)$.

Finally, a survey of the University of Athens (MediaanalysisGR, 2020) provides us with differentiated results, on the basis of a different sample of respondents, leaning to the left and the centre-left. According to this survey research, $63 \%$ follow the news internet sites, 57\% the social media, $31 \%$ the national television news programs, $25 \%$ the news blogs, $13 \%$ the radio news, and $4 \%$ the newspapers. Although $85 \%$ of the participants do not like the newspapers as news source, $26 \%$ of them consider the newspaper information as very useful. The 
sociohistorical and cultural context of a national society undoubtedly plays the most important role in the way people use the big variety of coronavirus news sources, and also perceive, frame and evaluate information (especially for the case of Italy, see the work of Briscese et al., 2020).

\section{Concluding remarks}

In some sense, COVID-19 is a digital pandemic in terms of its origin, dynamics and effect: "Governments around the world are resorting to digital instruments to combat the virus. Artificial intelligence and big data analysis play a valuable role herein" (Okano-Heijmans, 2020). The pandemic also sheds light on the intricate and intrinsic

"connection among the government, citizens and data. This connection is powered by the ever more astounding advances in information and communication technology (ICT) and, even more so, by our ability to make sense of large sets of data" (Visvizi and Lytras, 2020, p. 125).

All in all, this massive crisis could be attributed to historic dimensions, as long as history is the product of collective work, or the uncertain outcome of deliberative action of social and political agents (Gauchet, 2016, p. 374). Eventually, it is a multifaceted relational process connected to other crises which emerge in other systems (economy, politics, media, culture, family, etc.), and brings about immense harms on the body, soul, and social life. These crises will deeply imprint themselves in the memory of every society, as well as in the psychic background of the social subjects. The traumatic experience of the pandemic has shown for the first time how dangerous can be a speedy, functionally differentiated and highly networked world society, where the virus spreads far and wide in just a few days or weeks and affects all geographical areas (Esposito, 2020a; see also Esposito 2020b). In this regard, the pandemic can be theorised as a man-made social catastrophe (Leggewie, 2020).

Nowadays, the hyperconnected world corresponds to a model of society produced by the new phase of globalisation, which is fundamentally characterised by the constant increase of exchanges and interactions between national digital and virtual systems, as well as by the rapid diffusion of information, knowledge, innovation and services (Baldwin, 2019). This model strives to adapt to turbulences and difficult contexts, such as the COVID-19 context. It is still too early to foresee whether the coronavirus crisis will generate disruptive societal changes in the prospective reality of a serious economic crisis, or the tendency to return to normalcy will prevail. As soon as the virus turns its back, it is highly possible that the reign of the economists will give way to the government of the physicians (Gauchet, 2020b). In general, we can arguably conclude that the pandemic transforms the government in a dynamical fashion, albeit the scale of that impact is still unknown (Visvizi and Lytras, 2020, p. 126; Visvizi and Lytras, 2019).

In this analytic setting, it is important to understand that the emergent network society renders the contemporary media as the main agent of public reflection and orientation, and as the substitute of politics, economy and religion (Baecker, 2018). Given that the current societies relationally shape their technological systems and patterns of transmission, further empirical and theoretical interdisciplinary research is urgently needed on the role that the digital and printed media (including the diffused cultural formations) play in the information policy of national governments and in the perception of the pandemic by the people, as well as on the media's impact upon the pandemic society. 
Хараламбос Цекерис ${ }^{1}$

Национални центар за социолошка истраживања

Атина (Грчка)

Персефони Зери ${ }^{2}$

Универзитет друштвених и политичких наука „Пантеион”

Атина (Грчка)

\section{КРИЗА ИЗАЗВАНА КОРОНАВИРУСОМ КАО СВЕТСКИ ИСТОРИЈСКИ ДОГАЂАЈ У ДИГИТАЛНОЈ ЕРИ}

(Превоg In Extenso)

Сажетак: Светски историјски догађај попут пандемије COVID-19 још једном је потврдио да живимо у крајње повезаном светском друштву и да се у данашње време епидемије више не сматрају само природним појавама. У таквом контексту, овај рад има циљ да протумачи сложени однос између друштва и вируса COVID-19, ca нагласком на улози коју имају разне силе у области информационе политике и јавних перцепција уопште. Из тог разлога елаборирамо културолошке факторе, као и емоције попут одговорности, поверења и страха током кризе. Такође смо се усредсредили на динамику савремених медија у вези са јавним представама о пандемији, ослањајући се на релевантне налазе. У целини, тиме се у новом социолошком и интердисциплинарном светлу приказује садашња пандемија као односни процес и феномен покренут дигиталним медијима.

Кључне речи: криза изазвана коронавирусом, дигитални медији, поверење, страх, Грчка

\section{Увод: Држава, друштво и криза изазвана коронавирусом}

Свим посланицима у немачком парламенту 2012. године дата је прогностичка студија о сценарију велике пандемије потекле из Азије (Kiel, 2020). Занимљиво је то што студија тада уопште није узета у обзир. Сви су игнорисали слабе сигнале. Почетком 2020. године пандемија коронавируса (или COVID-19) неочекивано је стигла до запада као „црни лабуд” који брзо шири заразу, односно као процес који ће највероватније однети многобројне жртве (Taleb, 2020) услед повећане глобалне повезаности. Изгледа да ниједна национална и наднационална влада није била припремљена иако се управљање у принципу односи на стратешко промишљање и предвиђање (Tufekci, 2020). Прогностички сценарији подразумевају размишљање

\footnotetext{
${ }^{1}$ tsekeris@ekke.gr

2 persazeri@hotmail.com
} 
о будућности и посебне структуре за спровођење ванредних мера на основу јасних обавеза, процене ризика и учешћа стручњака (Kiel, 2020).

Оно што се сада дешава на западу јесте отворен процес дефинисања и заустављања пандемије коронавируса у којем наука (епидемиологија, инфектологија, имунологија и вирусологија), у условима велике неизвесности и непредвидивости, има водећу улогу заједно са јавном дебатом о перспективи у погледу медицинског третмана болести као нечега што се временом мења. У овим јавним дискусијама активно учествују разни актери, као што су штампани и дигитални медији, цивилно друштво и остале заинтересоване стране. Позитивну улогу у сакупљању информација о пандемији има глобална истраживачка мрежа универзитета и истраживачких установа који интензивно сарађују како би реаговале на COVID-19. То представља општу базу знања које се размењује у процесу доношења политичких одлука (Dianeosis, 2020). Распрострањено уверење о томе да се треба активно супротставити кризи и успешно је савладати подстиче огромне промене у понашању или ствара спремност на усаглашавање са траженом бихевиоралном оријентацијом (Dianeosis, 2020).

У том процесу људи изражавају спремност да преузму одговорност за себе и друге, следећи на тај начин посебна правила понашања када је реч о одржавању хигијене, на пример прање руку, ношење маске и социјална дистанца. У том погледу, владе покушавају да удруже одговорност коју људи показују са јавним поштовањем уведених правила, што наглашава конститутивну улогу државе у заштити друштва. Јавно придржавање мера за спречавање заразе (затварање школа, забрана великих скупова, спортских догађаја итд.) показује безусловно прихватање политике као најодговорнијег елемента у функционисању друштва у целини. Цивилно друштво (или породица) не могу да делују сами у овој ситуацији; то треба да уради држава. Ова чињеница постаје очигледна у предузимању финансијских мера огромних размера како би се подржала привреда и друштво који су снажно погођени кризом (Strauss-Kahn, 2020, str. 9; Rogoff, 2020). Брза реакција на кризу у већини европских држава и висок степен одобравања драстичних мера у јавности повезан је са крајњом „вредношћу људског живота која је знатно појачана у колективном несвесном најбогатијих земаља" (Strauss-Kahn, 2020, str. 8). Економија и остале друштвене активности стога морају да жртвују један део своје динамике у корист здравственог система (Baecker, 2020a). У овој историјској ситуацији сведоци смо „парадокса” пред демократским друштвима где се колективитет ставља у службу чисто одбрамбеног циља (Gauchet, 2020c).

Мере заустављања коронавируса и одржавања социјалне дистанце показују радикалан заокрет јер се уместо културе слободе и самоодређења наглашава култура осетљивости заштите (Bude, 2020) и колективне дисциплине. Ова промена указује на слабљење доминантне идеје о снажном „ја”, тј. о „идентитарној особи” (Ladeur, 2007, str. 397) која негира интернализацију (или индоктринацију) друштвених ограничења и усредсређује се на своју наводно „аутентичну” самопрезентацију, далеко од обичне стварности. Уместо тога, сада смо сведоци преовлађујуће идеје о слабом и рањивом „ја” којем је потребна заштита државе. Одговор државних власти у Грчкој, као и у већини земаља, нарочито када је реч о мерама затварања и изолације, прихватила је с поштовањем огромна већина становника (Dianeosis, 2020; Papamattheou, 2020). 
Хараламбос Цекерис, Персефони Зери, Криза изазвана коронавирусом као свейски...

Током периода изолације грађани су могли рефлексивно да посматрају како се јавља перцепција новог, ефикасног „ми” (Coyle, 2020), везано за идеју о личном продруштвеном развоју и широј друштвеној интеграцији и кохезији. Ово је такође повезано са препреком у виду политичке поларизације која је ендемска појава у политичком животу Грчке (Zeri et al., 2019). Али да ли је ово динамичка препрека? Наравно, нико не може лако предвидети да ли ће после кризе изазване коронавирусом поново доћи до стварања неповољне политичке климе, нарочито у контексту економске кризе непознатих размера која ће највероватније уследити (European Commission, 2020). У сваком случају, задатак политике у вези са научном неизвесношћу када је реч о производњи вакцине или делотворних лекова јесте да развије способност колективне акције и да у друштву учврсти веровање у успешан заједнички одговор на кризу. Влада такође мора да смисли и примени стратегије комуникације које постижу осетљиву „равнотежу између смањивања оптимистичке пристрасности не изазивајући претерану анксиозност и страх” (Bavel et al., 2020, str. 461). Поред тога, руководство мора да координише појединце и „да им помогне да избегну понашање које се више не сматра друштвено одговорним" (Bavel et al., 2020, str. 465).

Уплитање државе није повезано са технократским, наивним подређивањем науци нити са беспоговорном спремношћу на послушност. Грађани су били мишљења да нам је потребна демократска држава која заступа све нас и која може да санкционише појединце због општег добра (Bude, 2020). Јавна заштита један је од главних циљева демократске политике, поготово у стратешком напору да се изрази убедљив јавни интерес (Gostin \& Wiley, 2020) и да се људима помогне да помоћу јединства и солидарности преживе светско-историјску појаву коронавируса (Visvizi \& Lytras, 2020) и да сачувају хуманост људског рода. Занимљиво је то што резултати истраживања института Дианеосис (2020) потврђују представу Грка о држави која даје предност јавном здрављу, као и знању и одговорности стручњака. Током изолације смо, мада накратко, били сведоци спонтане појаве механизма солидарности и узајамне бриге (Fanaras, 2020, str. 17) који нам није наметнут из државног врха већ је заснован на осећању да нам је држава ипак потребна.

Такође смо доживели атмосферу резервисане солидарности (или идиосинкратске мешавине солидарности и сумње), чија је природа добила нову димензију; то јест, штитимо друге не само тако што им помажемо већ и тако што „одржавамо дистанцу” како би се спречила зараза. Свест о релативној осетљивости која не познаје класну припадност подстакла је потрагу за новим видовима солидарности. Интересантно је да 66,8\% Грка верује да криза изазвана коронавирусом има позитиван утицај на солидарност са другима (Georgakopoulos, 2020, str. 10). Међутим, још увек је рано доносити коначне и чврсте закључке о процесу учења који се односи на изградњу нових типова солидарности. Скорашње слике масовних демонстрација и јавних скупова у периоду када су правила о социјалном дистанцирању и даље била на снази, могу да укажу на недостатак грађанске свести, а могуће и на културолошку неспособност памћења. Сада прелазимо на елаборацију улоге различитих сила као што су емоције, култура и медији у области информационе политике, јавних ставова о вирусу COVID-19 и друштва током пандемије уопште. 


\section{Одговорност и поверење током пандемије}

У периоду спровођења наредби о „останку код куће” и тоталне изолације, велики терет јавних информација (преплављених смерницама којима је управљала грчка држава и које су преносили телевизија и радио) допринео је томе да људи схвате да су одговорни не само за себе већ и за друге. Током двомесечног карантина, чланови друштвене заједнице су научили да поштују обавезна правила. Озбиљност кризе постала је сасвим јасна када су се у медијима појавиле слике из Италије и САД-а на којима се виде конвоји како износе сандуке жртава коронавируса из Бергама или Њујорка, као и слике преоптерећених здравствених система. Имајући у виду да је пандемија најопаснија за старије особе и да у грчкој породици деде и баке имају значајну улогу (Dianeosis, 2020), исказано је готово апсолутно поштовање према мерама затварања.

Попуштање мера изолације у мају 2020. повезано је са строгим предусловима који су обавезивали људе да поштују рестриктивне мере. Ипак, млади људи и најосетљивији стари људи одједном су почели да се окупљају у парковима и поред мора, кршећи тако правила социјалног дистанцирања. Понашали су се као да су потпуно избрисали из сећања ризике од новог таласа COVID-19, као и упозорења које је у медијима дао високо цењени професор Сотирис Циодрас, вођа експертског тима имунолога и представник владе за комуникацију са јавношћу током здравствене кризе (Kathimerini, 2020). То је нагли заокрет од колективно дисциплинованог народа у народ који пркоси јавним интересима. Стога је очигледно колико су крхки јединство и кохезија подстакнути страхом током периода изолације, али и колико је снажна жеља за нормалношћу.

У европској свести, мир и просперитет, заједно са високим економским резултатима, проредили су стратешке прогнозе/размишљање о будућности и потиснули потенцијалну опасност и основну димензију политичког постојања. Истицање права појединаца и материјалних средстава постало је једини видљиви хоризонт, чиме је створено неосновано осећање сигурности (Gauchet, 2020a). Осим тога, постоје разлике у ставовима становника различитих европских земаља када је реч о мерама затварања у борби против коронавируса. Католичке земље попут Италије и Француске истичу се својеврсним спојем анархије појединаца и јавног ауторитарности, док се протестантске земље радије ослањају на осећај личне одговорности (Gauchet, 2020a).

У Грчкој посебно немамо ни наслеђе конфучијанске дисциплине нити можемо да се позовемо на наслеђе модерности и дубоко усађену свест о личној одговорности. Исказивање личне одговорности не припада „текстури” самоинституционалне политичке заједнице у грчком друштву, које обилује чврсто укорењеним предмодерним културним обрасцима (Demertzis, 1997, str. 109; Zeri et al., 2019, str. 8). На известан начин, грчки појединац је заточен у нерефлектованом „укорењеном ја” (Ramfos, 2011) и носи друштвена и психолошка упутства, као и моралне претпоставке породичног начина размишљања и стратегије уграђене у шире мреже интересних група (Pelagidis, 2012). Упркос томе, промена вредности у посткризном периоду свакако је могућа и заслужује анализу.

Суочивши се са великом здравственом кризом као што је пандемија COVID-19, која се односи на укуйну gрушитвену чињенииу (Kasuga, 2020), Грци су се ослонили на помоћ државе. Мноштво слика преминулих у медијима изазвало је психолошки шок 
који је могао да се ублажи само тежњом ка јединству и заједништву. Јединство народа гради се око државе и њених представника као стање заједништва, а не у контексту Европе или неке друге наднационалне организације. Међутим, треба напоменути да су ставови Грка према политичким институцијама у њиховој држави прилично негативни (Koniordos, 2018). Успех који је Мицотакисова влада остварила у управљању тзв. Евро кризом (јануар 2020) и кризом изазваном коронавирусом (март-април 2020) означио је упадљиву промену у представи коју Грци имају о својим политичким институцијама, нарочито о својој влади.

У поређењу са претходним истраживањима института Дианеосис, истраживање кризе изазване коронавирусом које је овај институт спровео у априлу 2020. године показало је упадљиво повећан степен поверења људи у државне институције, после чега следи јачање њиховог осећања оптимизма, сигурности и извесности на личном нивоу (Dianeosis, 2020). Исто тако, мере које је држава предузела током пандемије у циљу унапређивања јавног здравственог система учврстиле су поверење у саму државу (видети Kounias, 2020). Упадљиво је то што је поверење у науку (медицину) на самом врху лествице. Према истраживању коронавируса које је спровео Економски факултет у Атини, 50\% испитаника имају поверење у лекаре, $88 \%$ у здравствене раднике, а 57\% у државу, на ниском нивоу је њихово поверење у наставнике (45\%) и приватне компаније (24\%), док 75\% испитаника верује да су мере затварања биле ефикасне (Рараmattheou, 2020). Занимљиво је то што су политичко поверење, јасне поруке, транспарентна комуникација и разматрање свих битних питања пресудни за подстицање промене у понашању (Bavel et al., 2020, str. 466). Надаље, политичко руковођење и савладавање економске рецесије после пандемије COVID-19 биће несумњиво одлучујући фактор у развоју општег поверења у грчку политику.

\section{Страх у ери коронавируса}

Терористички напади на Њујорк 11. септембра 2001. означили су почетак ере страха. С временом су се осећања страха на различите начине повезивала прво са исламистичким тероризмом, затим са угрожавајућим климатским променама, а сада са великом глобалном здравственом кризом која снажно утиче на све нас (Bolz, 2020). У савременом богатом друштву многи људи посматрају пандемију COVID-19 као борбу за опстанак без преседана. До сада се држава налазила у служби економије и подстицала је слободно кретање капитала, људи и добара. Након глобалне појаве коронавируса опасног по живот, држава је успорила привреду због тога што су људски животи изложени ризику. Ово је потврда поштовања хуманистичке димензије на коју се позива модерност. Није реч о сйасеюь у смислу религијског искупљења (Finkielkraut, 2020a), већ о спасењу зgравља које је од почетка модерног доба „прво добро и основ свих осталих добара овог живота" (Descartes, 1953 [1637], str. 168). Према речима Алена Финкелкраута, морамо бити

„захвални политичарима којима је људски живот важнији од новца. Они су поставили праве приоритете зато што желе да сачувају најслабије и најрањивије припаднике друштва. [...] Докле год је живот старог човека вредан колико и живот човека на врхунцу физичке снаге, и даље ћемо бити цивилизовани" (Finkielkraut, 2020b). 
Међутим, у оквиру демократске заједнице, поготово у периодима друштвеног мира, људи дају предност сопственој појединачној слободи. Наиме, колективна машинерија у нормалним временима наводи нас да заборавимо да смо политичка заједница (Gauchet, 2020b). Када је реч о акутној кризи и колективној опасности, страх и осећање опште рањивости подстиче способност људи да поступају као грађани који своју заштићену егзистенцију дугују политичкој заједници, док се релативно потискује приоритет личне слободе. У исто време, за разлику од диктаторских или ауторитарних режима, људи (корисници интернета) имају слободу да у јавности дискутују и износе мишљења о мотивима јавних мера.

На основу резултата истраживања института Дианеосис (Fanaras, 2020, str. 6), успех који је грчка влада постигла у управљању кризом изазваном коронавирусом ограничио је негативна осећања страха и анксиозности. Стрпљење и креативност били су изненађујућа реакција на затварање читавог друштва у периоду дужем од шест седмица. Готово идентичне резултате дао је и Пројекат за спречавање коронавируса (Center for the Digital Future, 2020), који показују да су Американци током пандемије имали више времена за своје партнере и децу, односно да се поново посвете неком хобију и креативним активностима. Истраживање коронавируса које је спровео Економски факултет у Атини (Papamattheou, 2020) истиче висок ниво страха и анксиозности пре свега због економије (92\%), а мање због здравља (82\%).

\section{Медији и криза изазвана коронавирусом}

Пандемија коронавируса нагласила је високу сложеност глобалног система и његову повећану нелинеарну динамику (Tufekci, 2020), имајући у виду да се структурна форма светског друштва (Baecker, 2020b) и националних друштава односи на релационе мреже које се знатно разликују и репродукују (Baecker, 2018, str. 61). Наиме, здравствена криза коју тренутно доживљавамо потпуно се разликује од оних из прошлости, првенствено због тога што је свака економија у данашње време интегрисана у шири глобални контекст, при чему Кина представља „светску фабрику" (Strauss-Kahn, 2020, str. 19), док смо изгубили сећање на ризик од зараза, односно пандемија. У овом аналитичком окружењу, од пресудног је значаја елаборирати чињеницу да су, у оквиру умреженог друштва у којем живимо, медији као облик колективне рефлексије и оријентације заузели место политике, економије и религије (Baecker, 2018, str. 192). Из тог разлога, различити степени приступа квалитетним информацијама могу знатно да утичу на перцепције здравља, одлуке и исходе у контексту пандемије, док дезинформације на интернету могу да доведу до болести и смртног исхода у стварном свету (McGinty \& Gyenes, 2020, str. 4). Зато је грчка влада (као и владе осталих земаља чланица ЕУ) направила интернет страницу посвећену деконструисању митова о вирусу COVID-19 (covid19.gov.gr/mythoi-covid19/) у оквиру званичног портала за праћење овог вируса COVID-19 (covid19.gov.gr).

Поред тога, медији припадају оквирима различитих историјских, културолошких и институционалних контекста садашњих друштава која релационо обликују своје технолошке системе и обрасце преноса у ери глобално умрежених комуникација. Ово указује на фундаменталну улогу коју штампани и дигитални медији имају у информационој политици националних влада, као и у јавном поимању пандемије 
(видети нпр. Casero-Ripolles, 2020). Према најновијем истраживању Универзитета у Чикагу (Bertrand et al., 2020), Американци не посматрају пандемију кроз призму здравља и економије већ кроз призму властитих политичких уверења, властитог мишљења о правилној улози владе и поверења у медије у условима политичке поделе друштва. Поверење у медије је изузетно значајно за процену пандемије и одговор на њу (видети Merrefield, 2020). Треба напоменути да већина људи не процењује пандемију на основу онога што су видели или чули у јавним дискусијама, већ на основу тога за кога гласају, кога медији прате или кога домаћин емисије фаворизује (Bursztyn et al., 2020).

Према истраживању које је спровео Истраживачки центар „Пју”, идеолошки састав и партијска оријентација гледалаца кабловске мреже утиче на начин на који они процењују епидемију коронавируса (Pew Research Center, 2020a). Иако америчка јавност каже да медији добро обавештавају о кризи, дубоке поделе у погледу начина на који су медији извештавали о коронавирусу биле су очигледне не само између демократа и републиканаца, већ и између идеолошких сегмената унутар ове две странке (Pew Research Center, 2020d). На пример, у истраживању које је недавно спроведено у САД (Jamieson \& Albarracin, 2020) утврђено је да је гледање тзв. мејнстрим медија (нпр. NBC News) повезано са тачним информацијама о болести опасној по живот, док је читање мејнстрим штампаних медија (нпр. New York Times) повезано са тачним мишљењем о заштити од заразе, док су конзервативни медији (нпр. Fox News) у корелацији са теоријама завере.

Данас су електронски и дигитални медији преплављени негативним, сензационалистичким вестима и дезинформацијама о пандемији. У масовним медијима добро је познато како новинари све могу да претворе у лоше вести зато што су усмерени на масовну публику која у начелу реагује на лоше вести (Tierney, 2020). Негативне предрасуде и негативне информације су један од основних психолошких принципа (Baumeister, 2020). Осим тога, оне представљају кључну чињеницу о начину на који функционише човеков ум. Људи су склони да више значаја придају стварима које су пошле по злу него онима које су добре, до те мере да је довољан само један догађај да потпуно заокупи наше мисли (Baumeister \& Tierney, 2019). Негативне информације у човековом уму остављају својеврсан печат који није лако избрисати (Sunstein, 2020). Очигледно у својој подсвести тежимо да пажњу обраћамо на лоше вести (Hancock, 2020). Наиме, Гуљелмо Бришезе (Guglielmo Briscese) тврди да је много људи заражено и да нам се пандемија све више приближава, али људи и даље не мењају своје погледе (видети Merrefield, 2020).

Когнитивне и негативне предрасуде имају велики утицај на наш начин обраде вести (McIntyre, 2020). Пристрасност коју у свом мозгу потврђујемо подстиче нас да тражимо само оне информације које су у складу са оним у шта већ верујемо, а да одбацимо остале информације. Оваква пристрасност може нас спречити да сазнамо новости о пандемији и да се делотворно боримо против ње (McIntyre, 2020). Ипак, у друштву погођеном пандемијом, људи често живе у личном ванредном стању које може да прерасте у прави свет заблуде и да покаже изузетну крхкост психе. То доприноси ширењу теорија завере о корони у свим сегментима друштва (Bavel et al., 2020, str. 464ff.). У ери беспомоћности и нестабилности, због тога што су онемогућене важне психолошке потребе, теорије завере функционишу као инструмент 
управљања личном кризом (Douglas et al., 2017). Структура друштвених мрежа у неку руку олакшава процват и ширење лажних информација и вести о коронавирусу широм света, упркос координисаним напорима појединих компанија са дигиталним платформама (Fraenkel et al., 2020). Осим тога, Јан Филип Ремтсма (2020) истиче да је политичко размишљање прецењено и да заправо утицаји имају кључну улогу (видети и Demertzis, 2020). Људи ретко размишљају на политички начин (Reemtsma, 2020).

Начин на који Американци прате изворе вести о коронавирусу и сагледавају извештавање медија о пандемији суштински се разликује од начина на који Грци користе изворе информација о коронавирусу, а нарочито вести у медијима. Већина Американаца подједнако поклања пажњу националним и локалним вестима о COVID-19, при чему 56\% националних извора вести (укључујући штампу) представљају главни извор вести о коронавирусу, 51\% чине јавне здравствене организације и представници, 46\% локални извори вести, 31\% Доналд Трамп и радна група Беле куће задужена за извештавање о коронавирусу, 25\% међународни извори вести, $10 \%$ форуми и дискусионе групе на интернету, а 16\% пријатељи, породица и суседи (Pew Research Center, 2020b). Готово девет од десет испитаника сматра да је интернет основно или важно средство информисања током заразе коронавирусом (Pew Research Center, 2020c). У Грчкој је коришћење извора вести о коронавирусу пропраћено повећаним поверењем у вести у медијима (Fanaras, 2020), што је у складу са претходно поменутим повећањем поверења у политичке институције, а нарочито грчку владу. Грцима је главни извор вести о коронавирусу телевизија (48\%), затим следе интернет странице $(25,4 \%)$, здравствени радници $(9,1 \%)$, друштвене мреже $(7,5 \%)$, радио $(3,7 \%)$, породица и пријатељи $(2,9 \%)$ и новине $(1,8 \%)$.

Напослетку, истраживање Универзитета у Атини (Media analysis GR, 2020) даје нам диференциране резултате на основу различитог узорка испитаника који нагињу левици и левом центру. Према овом истраживању, 63\% испитаника прати вести на интернету, 57\% на друштвеним мрежама, 31\% прати национални дневник, 25\% блогове са вестима, 13\% вести на радију, а $4 \%$ чита новине. Иако $85 \%$ испитаника не воли новине као извор вести, њих $26 \%$ сматра информације из новина веома корисним. Друштвено-историјски и културолошки контекст националног друштва несумњиво има значајан утицај на начин на који људи користе мноштво разних извора вести о коронавирусу, као и на начин на који сагледавају, формулишу и вреднују информације (поготово у случају Италије, видети рад Briscese et al., 2020).

\section{Завршне напомене}

У извесном смислу, COVID-19 је gиіитиална йанgемија када је реч о пореклу, динамици и утицају: „Владе широм света прибегавају дигиталним средствима у борби против вируса. У томе драгоцену улогу имају вештачка интелигенција и обимна анализа података" (Okano-Heijmans, 2020). Пандемија такође баца светло на замршену и нераскидиву

„повезаност између владе, грађана и података. Ова повезаност је још јача услед задивљујућег напретка информационо-комуникационе технологије (ICT), а још више захваљујући нашој способности да схватимо велике низове података" (Visvizi \& Lytras, 2020, str. 125). 
У сваком случају, овој великој кризи могле би се приписати историјске димензије ако се сматра да је историја производ колективног рада или неизвесни исход делиберативног деловања друштвених и политичких агената (Gauchet, 2016, str. 374). На крају, ово је вишезначни релациони процес повезан са кризама које се јављају у другим системима (економија, политика, медији, култура, породица итд.) наносећи штету телу, души и друштвеном животу. Те кризе оставиће дубок траг у сећању сваког друштва, као и у психичкој позадини друштвених субјеката. Трауматично искуство изазвано пандемијом показало је први пут колико потенцијалне опасности носи брзо, функционално диференцирано и високо умрежено светско друштво, где се вирус назаустављиво шири за свега неколико дана или недеља и захвата сва географска подручја (Esposito, 2020а; видети и Esposito 2020b). У том погледу, пандемија може да буде теоретизована као вештачки створена друштвена катастрофа (Leggewie, 2020).

У данашње време хиперповезани свет одговара моделу друштва који је створен у новој фази глобализације, а чија је основна одлика стални пораст размене и интеракција између националних дигиталних и виртуелних система, као и брзо ширење информација, знања, иновација и услуга (Baldwin, 2019). Овај модел има за циљ прилагођавање турбуленцијама и тешким контекстима као што је контекст вируса COVID-19. Још је рано за прогнозе да ли ће криза изазвана коронавирусом довести до драстичних друштвених промена у перспективи озбиљне економске кризе или ће преовладати тежња ка повратку у нормалност. Када вирус буде нестао, сасвим је могуће да ће владавина економиста уступити место влади састављеној од лекара (Gauchet, 2020b). Уопштено узев, можемо без сумње закључити да пандемија трансформише владу на динамичан начин, иако је обим тог утицаја и даље непознат (Visvizi and Lytras, 2020, str. 126; Visvizi and Lytras, 2019).

У оваквом аналитичком окружењу важно је схватити да новонастало умрежено друштво савремене медије чини главним агентом јавног промишљања и усмерености, те да представља замену за политику, економију и религију (Baecker, 2018). С обзиром на то да данашња друштва релационо обликују своје технолошке системе и обрасце преноса, хитно су потребна даља емпиријска и теоретска интердисциплинарна истраживања о улози коју дигитални и штампани медији (укључујући и дифузне културне формације) имају у информационој политици националних влада и у перцепцији пандемије међу људима, као и о утицају медија на друштво погођено пандемијом.

\section{REFERENCES/ЛИTЕРATУPA}

Baecker, D. (2018). 4.0 oder Die Lücke die der Rechner läßt. Berlin: Verlag.

Baecker, D. (2020a). Corona I: Die pulsierende Gesellschaft. Blog Kultur/Reflexion, 27 March 2020.

Baecker, D. (2020b). Ohne Abstand: Über die Gesellschaft in Zeiten des Kontaktverbots. Neue Zürchner Zeitung, 16 April 2020.

Baldwin, R. (2019). The globotics upheaval: Globalization, robotics, and the future of work. Oxford: Oxford University Press. 
Baumeister, R., \& Tierney, J. (2019). The Power of Bad: How the negativity effect rules us and how we can rule it. New York: Penguin.

Baumeister, R. (2020). How to overcome your brain's fixation on bad things. Greater Good Magazine, 13 January 2020.

Bavel, J. J. V., Baicker, K., Boggio, P. S. et al. (2020). Using social and behavioural science to support COVID-19 pandemic response. Nat Hum Behav, 4, 460-471.

Bertrand, M. et al. (2020). How are Americans coping with the COVID-19 Crisis? Chicago: The University of Chicago Booth School of Business. Available at: https://www.chicagobooth.edu/research/rustandy/blog/2020/how-are-americans-coping-with-thecovid19-crisis-7-key-findings?sc_lang=en

Bolz, N. (2020). Wir leben im Zeitalter der Angst. Neue Zürcher Zeitung, 22 March 2020.

Briscese, G., Lacetera, N., Macis, M., \& Tonin, M. (2020). Compliance with covid-19 social-distancing measures in Italy: The role of expectations and duration (NBER Working Papers No. 26916). Cambridge, MA: National Bureau of Economic Research.

Bude, H. (2020). Legitimationsglaube, Folgebereitschaft und Verhaltensorientierung. Soziologische Perspektiven auf die Corona-Krise, 22 April 2020. Available at:https:// coronasoziologie.blog.wzb.eu/podcast/heinz-bude-legitimationsglaube-folgebereitschaft-und-verhaltensorientierung/

Bursztyn, L. et al. (2020). Misinformation during a pandemic. BFI Working Papers, 19 April 2020.

Casero-Ripolles, A. (2020). Impact of Covid-19 on the media system: Communicative and democratic consequences of news consumption during the outbreak. El profesional de la información, 29(2), e290223. Available at:https://doi.org/10.3145/epi.2020.mar.23

Center for the Digital Future (2020). The Coronavirus Disruption Project. Los Angeles: USC Annenberg School for Communication and Journalism. Available at:https://www.digitalcenter.org/coronavirus-study-findings,

Coyle, D. (2020). COVID-19 and the End of Individualism. Project Syndicate, 4 May 2020.

Demertzis, N. (1997). Greece. In R. Eatwell (Ed.), European Political Culture (pp. 107-121). London: Routledge.

Demertzis, N. (2020). The Political Sociology of Emotions: Essays on Trauma and Ressentiment. London: Routledge.

Descartes, R. (1953 [1637]). Discours de la Méthode, Sixième Partie. In A. Bridoux (Ed.), Descartes: Ceuvres et Lettres. Paris: Gallimard.

Dianeosis (2020). How Greeks live in the pandemic. Athens: diaNEOsis.

Douglas, K. M., Sutton, R. M., \& Cichocka, A. (2017). The psychology of conspiracy theories. Current Directions in Psychological Science, 26(6), 538-542.

Esposito, E. (2020a). The Need for De-Integration in Pandemic Times. TRAFO - Blog for Transregional Research, 18 May 2020. Available at:https://trafo.hypotheses.org/23985

Esposito, E. (2020b). Systemic Integration and the Need for De-Integration in Pandemic Times. Sociologica, 14(1), 3-20.

European Commission (2020). Spring 2020 Economic Forecast: A deep and uneven recession, an uncertain recovery. Available at:https://ec.europa.eu/info/business-economy-euro/economic-performance-and-forecasts/economic-forecasts/spring-2020-economic-forecast-deep-and-uneven-recession-uncertain-recovery en

Fanaras, S. (2020). In the Era of the Pandemic. Athens: diaNEOsis. 
Finkielkraut, A. (2020a). Le nihilisme n'a pas encore vaincu, nous demeurons une civilisation. Tribune Juive, 27 March 2020.

Finkielkraut, A. (2020b). Die Niederlage der Denker. Frankfurter Allgemeine Zeitung, 31 March 2020.

Frenkel, S., Alba, D., \& Zhong, R. (2020). Surge of Virus Misinformation Stumps Facebook and Twitter. The New York Times, 8 March 2020.

Gauchet, M. (2016). Comprendre le Malheur Français. Paris: Gallimard.

Gauchet, M. (2020a). Si cette crise pouvait être l'occasion d'un vrai bilan et d'un réveil collectif! Le Figaro, 26 March 2020.

Gauchet, M. (2020b). Les mondialisateurs n'ont pas rendu les armes. Le Causeur, 14 April 2020.

Gauchet, M. (2020c). Le lien qui nous unit à l'épreuve du Covid-19. France-Culture, 12 April 2020.

Georgakopoulos, T. (2020). How Greeks live in the pandemic. Athens: diaNEOsis.

Gostin, L. O., \& Wiley, L. F. (2020). Governmental public health powers during the COVID-19 pandemic: Stay-at-home orders, business closures, and travel restrictions. JAMA, 323(21), 2137-2138 doi:10.1001/jama.2020.5460

Hancock, J. (2020). People's uncertainty about the novel coronavirus can lead them to believe misinformation, says Stanford Scholar. Stanford News, 16 March 2020.

Jamieson, K. H., \& Albarracin, D. (2020). The Relation between Media Consumption and Misinformation at the Outset of the SARS-CoV-2 Pandemic in the US. The Harvard Kennedy School Misinformation Review. Available at: https://206.191.184.172/handle/1/42661740

Kasuga, N. (2020). Total Social Fact: Structuring, Partially Connecting, and Reassembling. Revue du MAUSS, 2(36), 101-110.

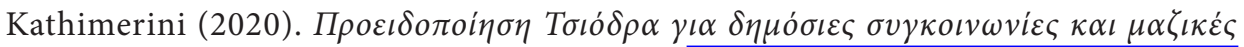

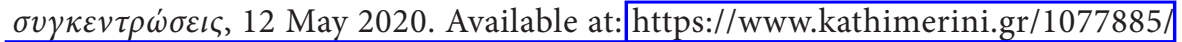
article/epikairothta/ellada/proeidopoihsh-tsiodra-gia-dhmosies-sygkoinwnies-kai-mazikes-svgkentrwseis

Kiel, E. (2020). Corona - die Unfähigkeit zu lernen? Merkur: deutsche Zeitschrift für europäisches Denken, 24 April 2020.

Koniordos, S. (2018). Main findings of the WVS-7 in Greece. Athens: diaNEOsis.

Kounias, D. (2020). GPO Survey. Parapolitika, 27 April 2020.

Ladeur, K. H. (2007). Verantwortung für Institutionen. In L. Heidbring \& A. Hirsch (Eds), Staat ohne Verantwortung? Frankfurt: Campus.

Leggewie, C. (2020). Corona-Pandemie: Namenloser Ausnahmezustand? CoronaఓSociety Blog, 15 May 2020.

McGinty, M., \& Gyenes, N. (2020). A dangerous misinfodemic spreads alongside the SARSCOV-2 pandemic. Harvard Kennedy School Misinformation Review (HKS), 12 May 2020.

McIntyre, K. (2020). Jill Suttie, How to Be Intentional About Consuming Coronavirus News. Greater Good Magazine, 30 March 2020.

MediaanalysisGR (2020). Greeks and the Coronavirus: A country in unprecedented conditions. Athens: Faculty of Communication and Media Studies, National and Kapodistrian University of Athens. 
Merrefield, C. (2020). Americans view the coronavirus pandemic through the lens of media trust and politics. Journalist's Resource, 12 May 2020. Available at:https://journalistsresource.org/studies/politics/polarization/media-trust-politics-lockdown-support/

Okano-Heijmans, M. (2020). Coronavirus: The world's first digital pandemic. Clingendael Magazine, 26 March 2020. Available at:/https://www.clingendael.org/publication/coronavirus-worlds-first-digital-pandemic

Pelagidis, T. (2012). Understanding the Crisis in Greece. Athens: Psychogios.

Pew Research Center (2020a). Cable TV and COVID-19: How Americans perceive the outbreak and view media coverage differ by main news source, 1 April 2020.

Pew Research Center (2020b). Americans are turning to media, government and others for COVID-19 news, 29 April 2020.

Pew Research Center (2020c). 53\% of Americans say the Internet has been essential during the COVID-19 outbreak, 30 April 2020.

Pew Research Center (2020d). Fewer Americans now say media exaggerated COVID-19 risks, but big partisan gaps persist, 6 May 2020.

Reemtsma, J. P. (2020). Impfangst als Weltverschwörung. Tageszeitung, 20 May 2020.

Rogoff, K. (2020). A coronavirus recession could be supply side with a 1970's flavor. The Guardian, 3 March 2020.

Strauss-Kahn, D. (2020). L'être, l'avoir et le pouvoir dans la crise. Politique Internationale, 10 April 2020. Available at https://www.leclubdesjuristes.com/letre-lavoir-et-le-pouvoir-dans-la-crise/

Sunstein, C. (2020). Why Coronavirus (and Other) Falsehoods Are Believable. Bloomberg, 31 March 2020. Available at:https://www.bloomberg.com/opinion/articles/ 2020-03-31/coronavirus-and-other-falsehoods-are-believable-research-shows

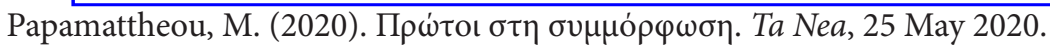

Taleb, N. N. (2020). The Statistical Consequences of Fat Tails. New York: STEM Academic Press.

Tierney, J. (2020). How to overcome your brain's fixation on bad things. Greater Good Magazine, 13 January 2020.

Tufekci, Z. (2020). It wasn't just Trump who got it wrong. The Atlantic, 24 March 2020.

Visvizi, A., \& Lytras, M. (Eds) (2019). Politics and Technology in the Post-Truth Era. Bingley: Emerald Publishing.

Visvizi, A., \& Lytras, M. (2020). Editorial. Transforming Government: People, Process and Policy, 14(2), 125-131.

Zeri, P., Tsekeris, C., \& Tsekeris, T. (2019). The social power dynamics of post-truth politics: How the Greek youth perceives the "powerful" foreigners and constructs the image of the European partners (Hellenic Observatory Papers on Greece and Southeast Europe, No 142). London: London School of Economics and Political Science. 